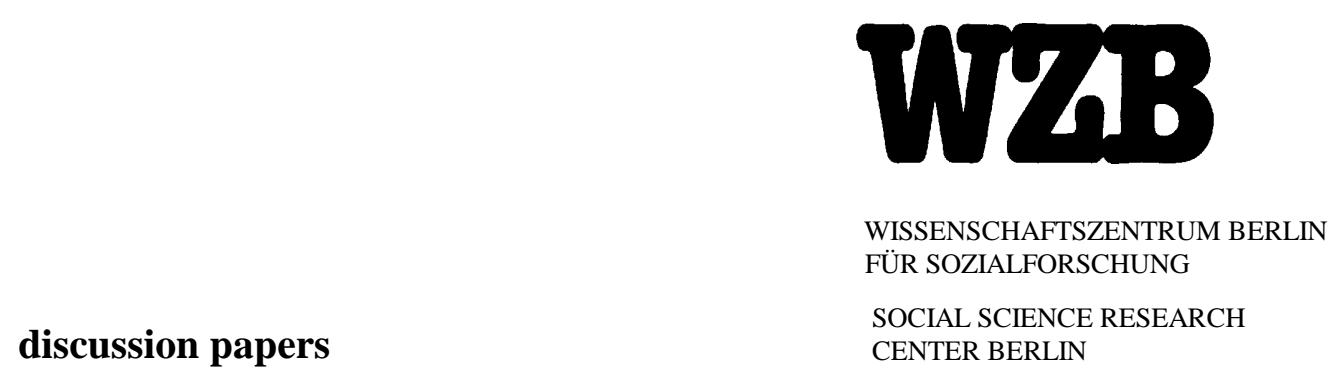

FS IV $01-12$

\title{
Merger Profitability and Trade Policy
}

Steffen Huck*

Kai A. Konrad**

* University College London and ELSE

** Wissenschaftszentrum Berlin für Sozialforschung

Juli 2001

ISSN Nr. 0722 - 6748

Forschungsschwerpunkt

Markt und politische Ökonomie

Research Area

Markets and Political Economy 


\section{Zitierweise/Citation:}

Steffen Huck, Kai A. Konrad, Merger Profitability and Trade Policy, Discussion Paper FS IV 01-12,

Wissenschaftszentrum Berlin, 2001.

Wissenschaftszentrum Berlin für Sozialforschung gGmbH, Reichpietschufer 50, 10785 Berlin, Tel. (030) 25491 - 0 Internet: www.wz-berlin.de 


\title{
ABSTRACT
}

\section{Merger Profitability and Trade Policy}

\author{
by Steffen Huck and Kai A. Konrad*
}

We study the profitability and welfare effects of merger in a strategic trade policy environment. Merger changes the strategic trade policy equilibrium. We show that merger can be profitable and welfare enhancing here, even though it is not profitable in a laissez-faire economy. A key element is the change in the governments' incentives to give subsidies to their local firms. We apply the results to the merger between Boeing and McDonnell-Douglas, where subsidies are a constant matter of debate. Our theory explains why the merger was profitable for Boeing and McDonnell-Douglas, why Airbus Industries opposed the merger, why the US authorities agreed to the merger, and why the EU competition authorities opposed it.

Keywords: Merger, strategic trade policy

JEL classification: D43, D44, F12, L11, L13

\section{ZUSAMMENFASSUNG}

\section{Fusionen und Handelspolitik}

Wir betrachten die Profitabilität und die Wohlfahrtseffekte von Unternehmensfusionen in einer internationalen Welt, in der Staaten das Instrument strategischer Außenhandelspolitik nutzen. Die Rückwirkungen der Fusionen auf die Wahl der strategischen Außenhandelspolitik machen Fusionen von Unternehmen des gleichen Landes profitabel, selbst wenn diese Fusionen in einer Welt ohne Außenhandelssubventionen nicht profitabel wären. Diese Resultate können erklären, weshalb die Fusion zwischen Boeing und McDonnell-Douglas profitabel war, weshalb Airbus unter der Fusion leidet und weshalb die US-Wettbewerbsbehörde der Fusion gegenüber positiver eingestellt war als die europäische Wettbewerbsbehörde.

\footnotetext{
The first author acknowledges support of the Economic and Social Research Council (UK). The work was part of the program of the ESRC Research Centre for Economic Learning and Social Evolution.
} 


\section{Introduction}

Horizontal merger is a frequent phenomenon, despite the fact that the incentives for such mergers are fairly obscure. In a linear Cournot market, for example, two firms never have an incentive to merge (see Salant, Switzer, and Reynolds 1983). The literature has invoked the cost advantages of a merger (Perry and Porter 1985), but the existence of such economies of scale or economies of scope is not well documented empirically.

An alternative explanation of why mergers take place has to do with the fact that firms operate in a more complex strategic environment. ${ }^{1}$ In this environment the merger may change the strategic context between the two merging firms and other players as well. In this paper we argue that merger changes the incentives for governments to use strategic trade policy. These changes may make a merger profitable from the perspective of the merging firms, and may even yield a welfare gain, from both a national and a world perspective.

The recent merger between Boeing and McDonnell Douglas can serve as an illustration. In the pre-merger situation there were three producers of large aircrafts: $\mathrm{A}$ (irbus), $\mathrm{B}$ (oeing) and $\mathrm{M}$ (cDonnel Douglas). $\mathrm{A}$ is located in country 1 (the EU), B and $\mathrm{M}$ are located in a different country 2 (the US). In the absence of strategic trade policy, the merger between Boeing and McDonnell-Douglas changed the situation from a triopoly to a duopoly in aircraft manufacturing. If competition in this industry is described by quantity competition (or, equivalently, by capacity choices with subsequent price competition) in an otherwise competitive world the merger is unlikely to increase the profits of the merging firms and unlikely to increase welfare in the US, or in the world as a whole.

Suppose now that the US and the EU use strategic trade policy and subsidize their own aircraft manufacturers. It is known that these subsidies have a strategic effect. Subsidies to one firm shift this firm's reaction function and this can improve the strategic position of the subsidized firm. Accordingly, a country that subsidizes its home firm induces output reductions in all other firms, and this stategic effect may increase the profits (and the welfare) in the country (Brander and Spencer 1985). Given that B and M are both located in the US, the situation is slightly different here. The US position in the pre-merger situation is unfortunate. If the US subsidizes B it will

\footnotetext{
${ }^{1}$ Two other papers add further strategic aspects to the picture. Lommerud, Straume and Sørgard (2001) consider the role of local or central wage bargaining for the profitability of merger. Coming from a different direction, Chae and Heidhues (2001) consider collusion of players in groups that bargain with each other and identify conditions when such collusion increases the colluding players' payoffs in 'non-pure' bargaining situations.
} 
harm not only A, but also M, a firm that is also located in the US. Paying strategic trade subsidies to one of their home firms has a cannibalizing effect as it harms the other firm located in the US. Accordingly, in the pre-merger situation, the fact that $\mathrm{B}$ and $\mathrm{M}$ are both located in the US puts the US in a disadvantageous position in the strategic trade game.

The merger removes this disadvantage. We would expect an increase in US strategic trade subsidies to BM, and, as an equilibrium effect, a reduction in EU strategic trade subsidies to A. As a result, we find that profits of BM in the new strategic trade equilibrium increase due to the merger, whereas profits of A decrease. Further, where all sales are made in a third country, the merger increases welfare in the country in which the merger takes place, and it reduces the welfare in the country whose firm is not involved in the merger.

We obtain this result for two different types of competition both of which may be relevant in many export industries. We first consider Cournot competition with linear cost, as in Salant, Switzer and Reynolds (1983). Cournot competition is the most commonly studied type of competition, and, due to the equivalence result by Kreps and Scheinkman (1983), it is more realistic than previously thought. ${ }^{2}$ We show that taking endogenous strategic trade policy into account fully reverses the results in Salant, Switzer and Reynolds (1983).

However, competition in export industries often has clear elements of a contest, and this is particularly relevant in hi-tech industries such as aircraft manufacturing, high-speed train systems, or defense industries (see Konrad 2000). ${ }^{3}$ We show that endogenous trade policy has effects for merger in markets with competition by contests similar to those in Cournot markets. It can increase the profitability of the merger, and it can increase the welfare of the country in which the merger occurs.

Coming back to the merger between Boeing and McDonnell-Douglas, strategic trade policy seemingly plays a major role in this market. Hidden subsidies are a perpetual matter of much debate between the major aircraft

\footnotetext{
${ }^{2}$ Kreps and Scheinkman (1983) show that straightforward quantity competition in a Cournot duopoly yields the same outcome as Bertrand price competition preceeded by capacity choice.

${ }^{3}$ For instance, with the launch of the A380 by Airbus that takes estimated USD 10.7 billion (Business Week, March 5, 2001, p.20) Airbus tries to earn monopoly rents in the market segment for aircrafts with more than 400 seats. Also the discounts of up to 40 percent on early orders (see Business Week, March 5, 2001, p.20) can be seen as "effort" in a contest for rents. Moreover, in defense procurement, applying for the contract is often seen as a contest and the firm that is awarded the contract is seen as the winner (see, e.g., Economist, August 12, 2000, p.69 on the Joint Strike Fighter (JSF) "...which will be the biggest defense procurement deal ever, worth up to USD 300 billion for the winner.")
} 
manufacturers, and the two countries in which they are located, ${ }^{4}$ both sides claiming that their competitor firm is highly subsidized, for instance, through defense contracts or preferential governmental loans. Our results can explain why firms like Boeing and McDonnell-Douglas merged, and why their competitors in other countries, such as Airbus Industries, disliked the merger. (Standard models invariantly predict that competitors gain from a merger of other firms.) It is well known that there was considerable opposition to this merger on the European side, whereas the US competition authority looked at the merger quite favorably (see, e.g., Economist, July 19th, 1997). If one assumes that national competition authorities care about national welfare, the results can also explain the different attitudes of European and US competition authorities towards the merger. Whether national competition authorities care about national welfare is not entirely uncontroversial in the literature. For instance, Neven and Röller (2000) note that antitrust agencies in the US and Europe formally operate with a bias in favor of consumers and look at whether this bias is counterbalanced by firms' lobbying activities. However, this tension may be less relevant for export industries. The fact that competition authorities often do not intervene if exporting firms cartellize their exports is revealing. Also, competition agencies are sometimes openly accused of national protectionism. ${ }^{5}$ The applicability of our results for interpreting the competition authorities' contradictory views depends on this assumption about the competition authorities' objectives. However, our results on the profitability and the welfare effects of the merger do not.

As optimal trade policy can be understood as a country's attempt to generate the amount of coordination among its exporting firms that is optimal from a national perspective, trade policy and merger policy are closely linked. This link has been highlighted in a number of papers. Head and Ries (1997) consider national incentives to block national mergers in an international context. The analysis by Richardson (1999) shows that "slack competition policy" is a substitute for trade restrictions: tariffs act as a coordination device that can change the behavior of a country's competitive industry towards behaving like a colluding group of suppliers who use their

\footnotetext{
${ }^{4}$ See, e.g., Wirtschaftswoche no. 21, May 17, 2001, p. 70.

${ }^{5}$ For instance, Jay Rockefeller, chairman of the US senate subcommittee on aviation, implicitly accused and threatened the EU commission in a letter to the commission vice president and transport commissioner Loyola de Palacio regarding the imminent EU decision on the merger between Honeywell and General Electric: "If it appears that the European Commission is unfairly blocking mergers between US companies principally to protect the position of European competitors, then the subcommittee will need to reexamine the open market the US has maintained for those sorts of acquisitions." (See Andrew Hill, Financial Times, June 21, 2001.)
} 
market power. A similar argument holds for price-taking consumers. Cowan (1989) considers competition policy and strategic trade policy with one importing country and one exporting country. Differently from these analyses, we consider firms' incentives to merge and show that strategic trade policy generates results that contrast with the results in Salant, Switzer and Reynolds (1983) that consider a similar framework in the absence of strategic trade policy. Section 2 considers merger and strategic trade policy in an international Cournot oligopoly. Section 3 considers the same game with competition by contests, and Section 4 concludes.

\section{Cournot competition}

Consider the merger problem as in Salant, Switzer and Reynolds (1983) in the context of strategic trade policy as in Brander and Spencer (1985). Suppose there are $n$ firms, located in $k$ countries. The set of firms is denoted by $N$ and the set of countries by $K$. The set of firms in country $j$ is denoted by $N_{j}$ and $n_{j}$ is the number of firms in country $j$. Accordingly, $\bigcup_{j \in K} N_{j}=N$ and $\sum_{j \in K} n_{j}=n$. For relevant cases, the number of countries and the number of firms in each country will be small, but our results are derived for the general case here.

The firms are owned by inhabitants of the country in which they are located. ${ }^{6}$ They produce a homogenous good and compete in a standard Cournot game. Each firm chooses its quantity $x_{i}$ simultaneously with all other firms. They sell their products exclusively in a market in a country that is not in the set $K{ }^{7}$ Before the firms choose their quantities, each country $j$ decides about subsidizing the sales of all firms located in this country by a per-unit subsidy. We limit consideration to cases where all firms in the same country have to receive the same per-unit subsidy, denoted $s_{j}$ for country $j .^{8}$

\footnotetext{
${ }^{6}$ This assumes away the possibility of internationally dispersed share ownership, where the profits of a firm located in country $i$ are part of country $j$ 's welfare. The assumption is in line with empirically well documented strong home country biases in portfolio composition. The assumption also fits with the Boeing-Airbus example, where Boeing and McDonnell-Douglas can be expected to have predominantly US shareholders and Airbus industries have predominantly European shareholders, including several European governments themselves. International dispersion of shareholdings changes the strategic environment. A paper that has highlighted this fact in a different context is Barros and Cabral (1994).

${ }^{7}$ Brander and Spencer (1985) make this assumption to remove considerations of consumer rent from the picture so as to single out and highlight the strategic interaction of firms. Consumer rents in the exporting countries are a matter of consideration in a broader analysis in which the results derived here remain relevant.

${ }^{8}$ While this non-discrimination provision is a plausible assumption (especially from a
} 
All $n$ firms observe the subsidy choices in all countries before they choose their quantities.

Demand for the homogenous good is downward sloping and linear and can, thus, be normalized to

$$
p(X)=1-X,
$$

where $X \equiv \sum_{i \in N} x_{j}$. We also follow Switzer, Salant and Reynolds (1983) and assume that all firms have the same constant cost $c$ per unit of output, and that this cost is not changed if a merger occurs.

In a completely unregulated world economy the Cournot equilibrium would entail $x_{i}=\frac{1-c}{n+1}$. Given the subsidies $\left(s_{1}, \ldots s_{k}\right)$, the $n$-player Cournot subgame for given subsidies has a different solution. Using (1), firm $i$ 's profit that is located in country $j$ can be written as

$$
\Pi_{i}=x_{i}\left(1-X-c+s_{j}\right)
$$

while welfare in country $j$ is described by the sum of the revenues of the country's firms net of production cost,

$$
W_{j}=\sum_{i \in N_{j}}(p(X)-c) x_{i} .
$$

The subsidy payments reduce government revenue and increase firm profits. Hence, they net out in the equation determining a country's welfare. The two-stage game is solved in the Appendix. We obtain

Lemma 1 Profit of a firm $i$ in country $j$ is

$$
\Pi_{i}^{*}\left(n, n_{j}\right)=\left[(1-c) \frac{n-n_{j}+1}{(k n+k-n+1) n_{j}}\right]^{2}
$$

while country j's welfare is

$$
W_{j}^{*}\left(n, n_{j}\right)=(1-c)^{2} \frac{n-n_{j}+1}{(k n+k-n+1)^{2}} .
$$

These results can be used to determine the consequences of a merger for firm profits and the welfare of the countries. We analyze the general case of a group of $m>1$ firms that merge. When stating our results we distinguish between firms that are involved in the merger, their competitors within the same country, and their competitors in other countries.

legal point of view), it is not clear a priori whether it restricts the generality of the results. Countries may want to pursue asymmetric strategies. 


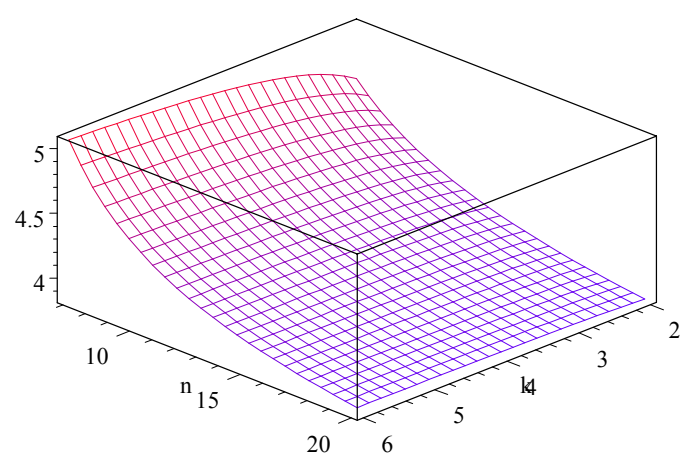

Figure 1: Critical $n_{j}$ for profitability of $m=2$ as a function of $k$ and $n$.

Proposition 1 (i) A merger in country $j$ is never profitable for firms in country $r \neq j$. (ii) A merger in country $j$ is always profitable for competitors in the same country. (iii) A merger is profitable for the group of merging firms in country $j$ if

$$
n_{j}<(m+\sqrt{m}) \frac{(k-1)(n-m)+2 k}{(k-1)(n-m-\sqrt{m}+1)+2}
$$

For a proof of Proposition 1 we compare the respective profits (4). The inequality of the third part of the result, which determines whether the merger is profitable or not, merits some attention. In general, it says that the number of firms in the country in which the merger takes place must not be too big. The critical size increases in the total number of firms $n$ and decreases in the number of countries. Thus, a merger of given size $m$ is rather profitable in an industry where there are many firms in a few countries than the other way round. A special case that is of particular interest is the case of a bilateral merger and Figure 1 plots the critical $n_{j}$ for $m=2$. It can be seen that bilateral mergers are rarely profitable if there are initially more than 5 firms in the country in which the merger is planned. Otherwise the reduction of the cannibalization effect is too small.

We will discuss this Proposition 1 further once we have established the next result on welfare.

Proposition 2 A merger of $m$ firms in country $j$ is always beneficial for country $j$. It can be harmful for other countries.

The proof of the first part of Proposition 2 follows from comparing the respective equilibrium welfare levels as described by (5). Further it is shown 
by an example below that the merger can be harmful for the welfare in other countries.

In the laissez-faire case considered by Salant, Switzer and Reynolds (1983) a firm which is not involved in the merger always benefits from the merger of other firms. This is true because two effects add: the merger reduces the number of competitors, and this yields a smaller total industry output, and hence, higher prices. Also, as firms' outputs are strategic substitutes in a Cournot oligopoly, a firm that is not involved in the merger will increase its equilibrium output. Hence, the firm gains from a larger own equilibrium quantity and a higher equilibrium price. Proposition 1 shows that this standard result is reversed in a strategic trade context. Firms that are not located in the country in which the merger occurs always lose if firms in another country merge.

The intuition for this result can be explained in the case with two countries 1 and 2 and three firms, A, located in country 1, and B and M, located in country 2 . Without a merger, country 2 faces the following problem. It wants to subsidize firm B; this subsidy induces firm B to choose a higher output, and anticipating this higher output, the other country's firm A chooses a smaller output in the equilibrium. This strategic effect on the other country's firms' output makes the strategic export subsidy attractive. However, the subsidy has a negative side effect here. Not only is firm A's output reduced. Country 2's second firm M will also reduce output if firm B is subsidized. This cannibalizing effect makes it less attractive for a country to use strategic trade policy if many firms are located in the country. If the two firms B and M merge, then this side effect disappears. Country 2 will use strategic trade policy more aggressively, and this will harm the firm in country 1.

The intuition for the welfare effects can be developed as follows. A merger does not change welfare and firm profits in the same direction in this framework. If firms merge in country 2 , this country can use strategic trade policy more efficiently and will make more use of it. Hence, for unchanged trade subsidies in other countries, this direct effect will increase the output of this country's firms and will harm the firms in other countries. The welfare benefit of this effect is typically smaller than the resulting profit increase, but typically goes into the same direction. Further, anticipating country 2's behavior, the other country 1 will typically use strategic trade policy less aggressively. This further benefits the firm(s) in country 2 and country 2's welfare.

For illustration we calculate the equilibrium subsidies for the two-countries three-firms case and find $s_{1}=\frac{1-c}{3}$ and $s_{2}=0$. As country 1's subsidy harms foreign competitors only, whereas country 2's subsidy has a cannibalizing 
effect, $s_{1}$ should be bigger than $s_{2}$. Calculating welfare in country 1 and in country 2 using these subsidy rates yields

$$
W_{1}=\frac{(1-c)^{2}}{12} \text { and } W_{2}=\frac{(1-c)^{2}}{18},
$$

and profits

$$
\pi_{A}=\frac{(1-c)^{2}}{4}, \text { and } \pi_{B}=\pi_{M}=\frac{(1-c)^{2}}{36} .
$$

Note that both welfare in country 1 and firm profits in country 1 are higher than welfare and the sum of firm profits in country 2 in this example, even though country 2 has two firms and country 1 has only one firm. If a merger of firms $\mathrm{B}$ and $\mathrm{M}$ occurs, the equilibrium subsidies are $s_{1}=s_{2}=\frac{1-c}{5}$. This leads to welfare equal to

$$
W_{1}=W_{2}=\frac{2}{25}(1-c)^{2}
$$

and profits equal to

$$
\pi_{A}=\pi_{B M}=\frac{4}{25}(1-c)^{2} .
$$

Comparing these profits and welfare levels shows that, for the linear case considered, country 2 gains from the merger in terms of both increased firm profits and increased total rent or welfare. The competitor in country 1 loses and the welfare in country 1 is also reduced. The laissez-faire results in Salant, Switzer and Reynolds (1983) are fully reversed. Hence, strategic trade policy explains why merger is profitable for the merging firms and bad for competitors in other countries.

\section{$3 \quad$ R\&D, and promotional competition}

Cournot competition is probably the most frequently studied type of competition, and, in order to emphasize the importance of a strategic trade policy environment for profitability and welfare implications of merger, we considered strategic trade policy in a set-up that stays as closely as possible with the analysis of merger by Salant, Switzer and Reynolds (1983), showing that their results on profitability and welfare reverse in this case. However, as discussed in the introduction, R\&D contests and other types of contest competition, for instance, promotional competition (Schmalensee 1976, 1992) may describe the competition among many exporting industries (including aircraft manufacturing) more suitably. Hence, in what follows we consider 
contest competition between firms, and analyze the impact of merger in a strategic trade environment.

A general description of contest competition is as follows. Firms spend effort in order to win a prize $V$. We normalize this prize to $V \equiv 1$. For simplicity, this prize is exogenously given. The prize can be the profit of the winner of a patent race, or the monopoly profit of a firm which successfully bribes the government, or industry profit in an industry in which product prices are fixed, etc. Accordingly, the type of effort can be R\&D investment, lobbying expenditure, bribes, expenditure on promotion, etc. In the contest the prize is allocated according to a contest success function

$$
q_{i}(\mathbf{e})=\frac{e_{i}}{E}
$$

where the $e_{i}$ is a non-negative amount of resources firm $i$ spends on the contest activity,

$$
E \equiv \sum_{j \in N} e_{j}
$$

is the sum of all efforts, and $\mathbf{e}$ is the vector of all firms' contest efforts. In some instances, e.g., promotional competition, $q_{i}$ can be interpreted as the share in the whole market which firm $i$ will have. In many other cases $q_{i}$ can be interpreted as the probability of firm $i$ winning the prize. The probability that this firm wins the prize is higher if the firm's own effort is higher and if the other firms' total effort is lower. The interpretations of $q_{i}$ as market share or as win probability will both lead to equivalent payoff functions.

The contest success function (11) is a 'short cut' that is well justified. It has been used, e.g., by Schmalensee (1992) for describing promotional competition. It also adequately describes the outcome of probabilistic $R \& D$ models. For instance, (11) is the success probability of firm $i$ in an R\&D contest in which firms $j \in N$ spend $e_{j}$ dollars in R\&D effort, and in which the winner is the firm for which $e_{j} \tilde{\theta}_{j}$ is largest, where $\tilde{\theta}_{j}$ are independent draws from an exponential distribution (see Hirshleifer and Riley 1992, p.380n.). Other stochastic R\&D-models leading to the same success function have been analyzed in Fullerton and McAfee (1999), and in Baye and Hoppe (2001). The contest success function (11) has also been axiomatized by Skaperdas (1996).

In what follows we will consider the case $K=\{1,2\}$ with $n_{1}$ firms in country 1 and $n_{2}$ firms in country 2 . The analysis can be generalized to many countries, but, because of possible corner solutions, not very elegantly. The two-country case is much more straightforward but still rich enough to analyse and understand the main strategic problems that arise when trade policy and mergers interact in contests. The governments in the two countries 
may subsidize the innovation efforts by proportional subsidy rates $s_{1}$ and $s_{2}$, respectively. The subsidy reduces the cost of firm $i$ in country $j$ from $e_{i}$ to $\left(1-s_{j}\right) e_{i}$. We assume that the subsidy rates are constrained to $s_{j} \leq s_{\max }<1$. The maximum requirement $s_{\max }$ means that governments are not able to assume the whole cost of effort, or even more than this cost. We will allow for negative subsidy rates, in which case the country taxes contest effort.

The same timing as in the Cournot game in section 2 applies: first the two countries simultaneously choose their subsidies, $s_{1}$ and $s_{2}$. Then these subsidies are observed by all firms and, hence, are known to the firms when they make their (simultaneous) effort choices.

The firms' payoff functions are

$$
\Pi_{i}=\frac{e_{i}}{E}-\left(1-s_{j}\right) e_{i} \equiv \sigma_{i}-a_{j} \sigma_{i} E
$$

for firm $i$ in country $j$. The definitions of the share in total effort, $\sigma_{i} \equiv e_{i} / E$ and the unit effort cost $a_{j} \equiv\left(1-s_{j}\right)$ net of subsidies/taxes that are made implicitly by the second equality in (13) are convenient when solving for the equilibrium. ${ }^{9}$ In turn, the welfare in country $j$ is

$$
W_{j}=\sum_{i \in N_{j}}\left(q_{i}(\mathbf{e})-e_{i}\right)=\sum_{i \in N_{j}} \sigma_{i}(1-E) \quad \text { for } j=1,2 .
$$

In Appendix B we confirm the following result:

Lemma 2 Profits for firms $i$ in country 1 and welfare in country 1 in an interior equilibrium of the contest model with strategic trade policy are given by

$$
\Pi_{i}^{*}\left(n_{1}, n_{2}\right)=\frac{\left(n_{2}-1\right)^{2}}{n_{1}^{2}(n-2)^{2}} \quad \text { for } i \in N_{1}
$$

and

$$
W_{1}^{*}\left(n_{1}, n_{2}\right)=\frac{n_{2}-1}{(n-2) n},
$$

and analogously for country 2.

These results can be used to assess the consequences of a merger in an industry in which competition is characterized by a contest. Given the random innovation process described by Hirshleifer and Riley (1992, p. 380n.), or promotional competition as in Schmalensee (1992), merger of a subset of

\footnotetext{
${ }^{9}$ Cornes and Hartley (2001) were the first to consider the contest problem in terms of contribution shares and aggregate contributions. This method simplifies the algebra even in cases with more than two heterogenous contestants.
} 


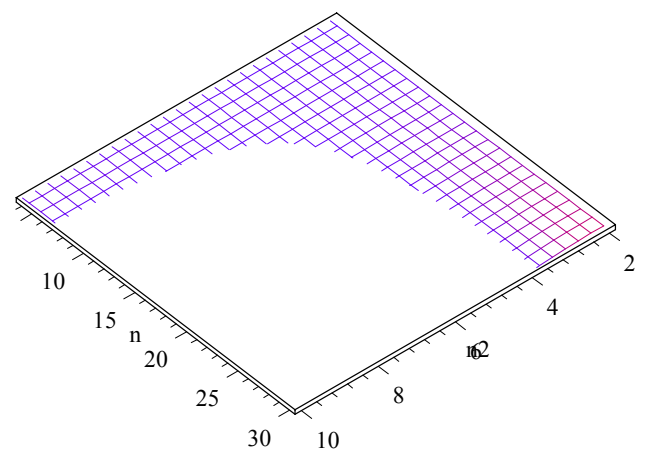

Figure 2: Combinations of $n$ and $n_{2}$ for which a bilateral merger is profitable. Notice that, of course, $n>n_{2}$ has to hold what is not considered in the figure.

$M \subset N_{j}$ of firms in one country simply means that the merged firms jointly choose the amount spent on contest effort $\sum_{i \in M} e_{i}$ to maximize their joint profits. ${ }^{10}$ The win probability for a firm $i$ becomes $q_{i}=e_{i} / E$ if the firm is not in the set of merging firms, and the joint win probability for the firms in the set $M$ of merging firms is $\sum_{i \in M} \frac{e_{i}}{E}$.

Proposition 3 Let there be $n_{1}$ and $n_{2}$ firms in country 1 and 2, respectively. Consider a merger of $m$ firms in country 2. If the equilibrium is in the interior before and after the merger, then (i) the merger harms competitors in country 1 if $n_{1}>1$ and does not change their profits if $n_{1}=1$. (ii) The merger benefits competitors of the merging firms in country 2. (iii) The set of merging firms gains if $\left(n_{2}\right)^{2}(n-2)^{2}>m\left(n_{2}-m+1\right)^{2}(n-m-1)^{2}$.

A proof compares the relevant expressions for profits that are obtained from (15). For the special case of a bilateral merger, Figure 2 shows combinations of $n$ and $n_{2}$ for which the merger is profitable. As with Cournot competition, it can be seen that bilateral mergers only pay if there are not too many firms in the country in which the merger takes place. Typically, a bilateral merger pays here if there are three or two firms in the country and does not if there are more.

The change in welfare in the two countries is as follows.

Proposition 4 Let there be $n_{1}$ and $n_{2}$ firms in country 1 and 2, respectively. Consider a merger of $m$ firms in country 2. Assume that the equilibrium

\footnotetext{
${ }^{10}$ In Huck, Konrad, and Müller (2001) we discuss alternative meanings of merger in contest models.
} 
is an interior equilibrium with and without the merger for all firms. The merger increases welfare in country 2. It decreases welfare in country 1 if $n_{2}[1-2 n+m]>1+m-n^{2}$.

A proof compares levels of welfare with and without the merger using (16). The results in Lemma 2 and Propositions 3 and 4 are very similar to the results obtained for Cournot competition. Strategic trade policy makes merger and acquisition in a country more beneficial for the firms in this country and increases welfare in this country. It harms foreign competitors and may reduce welfare in the foreign country. However, these results are valid only for equilibria in the interior of the strategy space. The game considered here frequently has corner solutions. We will therefore consider an example with $n_{1}=1, n_{2}=2$ and $m=2$, that fits well with with the merger between Boeing and McDonnell-Douglas. There is one firm A in country 1 and two firms $\mathrm{B}$ and $\mathrm{M}$ in country 2 if no merger occurs. The reaction functions are parametric cases of (31) and (32) in the Appendix, but take into account restrictions on subsidies, $s_{j} \in\left[s_{\min }, s_{\max }\right]$, with $s_{\max }<1$ and $s_{\min }<-1$ :

$$
\begin{gathered}
a_{1}=\max \left\{\frac{6 a_{2}-4\left(a_{2}\right)^{2}}{2 a_{2}+1},\left(1-s_{\max }\right)\right\} \text { and } \\
a_{2}=\max \left\{\min \left\{2-\frac{a_{1}}{2},\left(1-s_{\min }\right)\right\},\left(1-s_{\max }\right)\right\} .
\end{gathered}
$$

For the case with $s_{\min } \leq-1$, the strategic trade equilibrium is characterized by

$$
\begin{gathered}
s_{1}=s_{\max } \text { and } \\
s_{2}=-\frac{1+s_{\max }}{2} .
\end{gathered}
$$

For these equilibrium values, profits of firms and welfare of countries in the equilibrium for $s_{\max } \in(0,1)$ are

$$
\begin{gathered}
\Pi_{A}=\frac{1}{4}\left(1+s_{\max }\right)^{2} \text { and } \Pi_{B}=\Pi_{M}=\frac{1}{16}\left(1-s_{\max }\right)^{2} \text { and } \\
W_{1}=\frac{1}{4}+\frac{s_{\max }}{4}, \text { and } W_{2}=\frac{1}{4}-\frac{s_{\max }}{4}
\end{gathered}
$$

respectively.

To assess the implications of a merger between $\mathrm{B}$ and $\mathrm{M}$ we solve for the equilibrium of an analogous game in which there is one firm A in country 1 , and one firm BM in country 2 that resulted from the merger between $B$ and $M$. For the two resulting firms in countries 1 and 2, respectively, the contest 
equilibrium is characterized by $\sigma_{A}=1-\frac{a_{A}}{a_{A}+a_{B M}}, \sigma_{B M}=1-\frac{a_{B M}}{a_{A}+a_{B M}}$, and $E=$ $\frac{1}{a_{A}+a_{B} M}$. Substituting these equations in the welfare function $W_{1}=\sigma_{A}-\sigma_{A} E$ and differentiating yields country 1's reaction function $a_{1}\left(a_{2}\right)=2-a_{2}$ and country 2's reaction function $a_{2}\left(a_{1}\right)=2-a_{1}$.

Accordingly, the strategic trade equilibrium has multiple equilibria but only one that is symmetric, with $s_{1}=s_{2}=0$. This symmetric equilibrium leads to profits and welfare levels of

$$
\Pi_{A}=W_{1}=\Pi_{B M}=W_{2}=\frac{1}{4} .
$$

Comparing the welfare levels in the situation without a merger to the welfare levels in the situation with a merger, the outcome generally depends on which equilibrium is chosen in the case with a merger. But as $a_{1}+a_{2}=2$ in any equilibrium, we obtain

$$
W_{1}=\frac{1}{4}+\frac{s_{1}}{4} \text { and } W_{2}=\frac{1}{4}-\frac{s_{1}}{4}
$$

with $s_{1}=-s_{2}$ in equilibrium. This shows that regardless of the equilibrium selected country 2 is better off if $\mathrm{B}$ and $\mathrm{M}$ merge. ${ }^{11}$ However, it seems intuitive to select the unique symmetric equilibrium in the post-merger game. This case is summarized in the following

Proposition 5 If $n_{1}=1$ and $n_{2}=2$, a merger in country 2 has the following effects: (i) the country in which the merger occurs benefits from the merger, (ii) the other country loses from the merger, (iii) the merging firms benefit from the merger, and (iv) the firm that is not involved in the merger loses from the merger.

\section{Conclusions}

In this paper we consider the profitability of merger in an international context in which governments use strategic trade policy. The analysis is stimulated by the takeover of McDonnell-Douglas by Boeing and other recent takeover attempts among firms which compete for high-tech products in international markets, and in which strategic trade policy is a particularly relevant aspect. We show that strategic trade policy can be a key explanation of why mergers between firms in the same country occur. We can also

\footnotetext{
${ }^{11}$ The only exception is the extreme case in which $s_{1}=s_{\max }$ in which country 2's gain is zero.
} 
explain why the country in which the merger takes place may gain whereas other countries and competing firms in these other countries may lose.

It is well known that merger can harm firms. For instance, in Cournot markets, the merger increases industry profits, but decreases the merged firms' share in these profits, and the latter effect can overcompensate the former. With strategic trade policy, however, there is an additional effect. The merger of two firms in one country increase this country's incentives to use strategic trade policy, and, in turn, a trade policy equilibrium emerges in which the country in which the merger occurred chooses higher trade subsidies and the country in which no merger occurred chooses lower trade subsidies. This, in turn, benefits the merging firms (Boeing and McDonnellDouglas in our example) and harms the firm that is not involved in a merger (Airbus). This trade-policy effect of merger can overcompensate the effects that make a merger unprofitable in a laissez-faire world for the case of quantity competition and for other forms of competition, like, for example, R\&D contests or promotional competition. Accordingly,

- firms involved in the merger can benefit from the merger,

- firms not involved in the merger can lose from the merger of firms in another country,

- the country in which the merger occurs can gain from the merger, and

- the country in which the firm is located that is not involved in the merger can lose from the merger.

Apart from explaining the incentives for the merger between Boeing and McDonnell-Douglas, our results predict that Boeing will receive bigger subsidies after the merger, and Airbus will receive smaller governmental subsidies in the future.

The finding in this section illustrates a more general point. Merger activities are part of a more complex strategic game, and the merger changes actions made by players other than the firms involved in the merger and their competitors. These strategic effects should not be neglected when assessing the profitability of a merger. 


\section{A Solution of the two-stage Cournot oligopoly with strategic trade policy}

We look only for subgameperfect equilibria of the two-stage game of Cournot oligopoly in a strategic trade environment. Sometimes we will use a superscript $i$ with the subsidy variable; $s^{i}$ signifies the subsidy which firm $i$ receives. As all firms in a country receive the same subsidy, $s^{i}=s^{r}=s_{j}$ holds for all firms $i$ and $r$ in country $j$. It will be convenient to use $S \equiv \sum_{i \in N} s^{i}=$ $\sum_{j \in K} n_{j} s_{j}$.

For given trade subsidies, firm $i$ 's best-response function can be written implicitly as

$$
x_{i}-s^{i}=1-X-c .
$$

Taking the sum of all left-hand and all right-hand sides of (19) we obtain the total quantity $X$ as a function of the "total subsidies" $S$. Substituting into (19) yields the equilibrium quantities as

$$
x_{i}^{*}=\frac{1-c-S}{n+1}+s^{i} .
$$

Firm $i$ 's profits are given by

$$
\Pi_{i}=\left(x_{i}^{*}\right)^{2}
$$

and country $j$ 's welfare by

$$
W_{j}=\sum_{i \in N_{j}} x_{i}^{*}\left(p\left(X^{*}\right)-c\right)=\sum_{i \in N_{j}} x_{i}^{*}\left(x_{i}^{*}-s_{j}\right) .
$$

This describes the Cournot outcome for given subsidies. We now turn to the strategic trade policy game in which each country maximizes (22) by a choice of $s_{j}$. Country $j$ 's best response function is obtained by differentiating (22) with respect to $s_{j}$.

$$
\begin{aligned}
\frac{d W_{j}}{d s_{j}} & =\sum_{i \in N_{j}}\left(\frac{\partial x_{i}^{*}}{\partial s_{j}}\left(2 x_{i}^{*}-s_{j}\right)-x_{i}^{*}\right) \\
& =\sum_{i \in N_{j}}\left(x_{i}^{*} \frac{n+1-2 n_{j}}{n+1}-s_{j} \frac{n+1-n_{j}}{n+1}\right) .
\end{aligned}
$$


Using symmetry of firms within the same country the resulting first-order condition can be written as

$$
s_{j}=x_{i}^{*} \frac{n+1-2 n_{j}}{n+1-n_{j}} \text { with } i \in N_{j}
$$

Substituting $x_{i}^{*}$ by (20) the first-order condition can be rewritten as

$$
s_{j} n_{j}=(1-c-S) \frac{n+1-2 n_{j}}{n+1} .
$$

Summing both sides of (23) over countries gives

$$
S=(1-c-S)\left(k-\frac{2 n}{n+1}\right) .
$$

Hence, in equilibrium

$$
S=(1-c) \frac{k(n+1)-2 n}{k(n+1)-n+1}
$$

Inserting (24) into (23) and re-arranging gives the equilibrium subsidies as

$$
s_{j}^{*}=(1-c) \frac{\left(n+1-2 n_{j}\right)}{(k n+k-n+1) n_{j}} .
$$

Hence, by (20) and (21 ) firm $i$ in country $j$ supplies

$$
x_{i}^{*}=(1-c) \frac{n-n_{j}+1}{(k n+k-n+1) n_{j}}
$$

and earns

$$
\Pi_{i}^{*}=\left[(1-c) \frac{n-n_{j}+1}{(k n+k-n+1) n_{j}}\right]^{2} .
$$

Accordingly, we can compute country $j$ 's welfare as

$$
W_{j}^{*}=(1-c)^{2} \frac{n-n_{j}+1}{(k n+k-n+1)^{2}} .
$$

This concludes the proof. 


\section{B Solution of the two-stage contest game with strategic trade policy}

Consider first the contest subgame. Firms' first-order conditions are $\sigma_{i}=$ $1-a_{j} E$. Using $\sum_{i \in N} \sigma_{i}=1$ this yields

$$
E=\frac{n_{1}+n_{2}-1}{n_{1} a_{1}+n_{2} a_{2}},
$$

which leads to the equilibrium share

$$
\sigma_{i}=1-a_{j} \frac{n_{1}+n_{2}-1}{n_{1} a_{1}+n_{2} a_{2}} .
$$

for a firm $i$ in country $j$. Substitution of these values in the welfare functions (14) and calculation of the first-order conditions with respect to $a_{1}$ and $a_{2}$, respectively, yields countries' reaction functions

$$
a_{1}=n_{2} a_{2} \frac{2 n_{1}-n_{2} a_{2}+n_{2}-1}{n_{1}\left(n_{2} a_{2}+n_{2}-1\right)}
$$

and

$$
a_{2}=n_{1} a_{1} \frac{2 n_{2}-n_{1} a_{1}+n_{1}-1}{n_{2}\left(n_{1} a_{1}+n_{1}-1\right)} .
$$

Note that $a_{1}$ and $a_{2}$ cannot be negative, because $s_{\max }<1$. Accordingly, for a huge set of parameters there can be a corner solution in which one country chooses the maximum subsidy, and the other country reacts optimally to this choice. An example with $n_{1}=1$ and $n_{2}=2$ is discussed in the main text. If there is an interior solution, it is determined by

$$
a_{1}=\frac{n_{1}^{2}+n_{1} n_{2}-n_{1}-n_{2}}{\left(n_{1}-2+n_{2}\right) n_{1}}
$$

and

$$
a_{2}=\frac{n_{2}^{2}+n_{1} n_{2}-n_{1}-n_{2}}{\left(n_{1}-2+n_{2}\right) n_{2}} .
$$

Accordingly, total contest effort is

$$
E=\frac{n_{1}+n_{2}-1}{n_{1}+n_{2}}
$$

and each firm in country 1 and in country 2 spend shares

$$
\sigma_{1}=\frac{n_{2}-1}{\left(n_{1}+n_{2}-2\right) n_{1}}
$$


and

$$
\sigma_{2}=\frac{n_{1}-1}{\left(n_{1}+n_{2}-2\right) n_{2}} .
$$

respectively. These results are substituted into (13) and (14) to obtain the equilibrium profits and the welfare as in Lemma 2.

\section{References}

[1] Barros, P.P., and L. Cabral, 1994, Merger policy in open economies, European Economic Review, 38, 1041-1055.

[2] Baye, M., and H. Hoppe, 2001, Duality of rent-seeking and innovation games, mimeo.

[3] Brander, J., and B. Spencer, 1985, Export subsidies and international market share rivalry, Journal of International Economics, 18, 83-91.

[4] Chae, S., and P. Heidhues, 2001, Nash bargaining solutions with coalitions and the joint bargaining paradox, WZB Discussion Paper FS IV 01- 01-15.

[5] Cowan, S., 1989, Trade and competition policies for oligopolies, Weltwirt- schaftliches Archiv, 125, 464-483.

[6] Fullerton, R.L., and R. Preston McAfee, 1999, Auctioning entry into tournaments, Journal of Political Economy, 107, 573-605.

[7] Head, K., and J. Ries, 1997, International mergers and welfare under decentralized competition policy, Canadian Journal of Economics, 30, 1104-1123.

[8] Hirshleifer, J. and J.G. Riley, 1992, The Analytics of Uncertainty and Information, Cambridge University Press, chapter 10, 369-404.

[9] Huck, S., K.A. Konrad and W. Müller, 2001, Merger and collusion in contests, mimeo.

[10] Konrad, K.A., 2000, Trade contests, Journal of International Economics, 51, 217-334.

[11] Kreps, D. and J. Scheinkman, 1983, Quantity precommitment and Bertrand competition yield Cournot outcomes, Bell Journal of Economics, 14, 326-337. 
[12] Lommerud, K.E., O.R. Straume, and L. Sørgard, 2001, Merger profitability in unionized oligopoly, CEPR Discussion Paper no. 2738.

[13] Neven, D.J., and L.-H. Röller, 2000, Consumer surplus vs. welfare standard in a political economy model of merger control, WZB discussion paper FS IV- 00-15.

[14] Perry, M.K., and R.H. Porter, 1985, Oligopoly and the incentive for horizontal merger, American Economic Review, 75, 219-227.

[15] Richardson, M., 1999, Trade and competition policies: concordia discors? Oxford Economic Papers, 51, 649-664.

[16] Salant, S., S. Switzer, and R. Reynolds, 1983, Losses from horizontal merger: the effects of an exogenous change in industry structure on Cournot-Nash equilibrium, Quarterly Journal of Economics, 48, 185199.

[17] Schmalensee, R., 1976, A model of promotional competition in oligopoly, Review of Economic Studies, 43, 493-507.

[18] Schmalensee, R., 1992, Sunk costs and market structure, a review article, Journal of Industrial Economics, 40, 125-134.

[19] Skaperdas, S., 1996, Contest success functions, Economic Theory, 7, 283-290. 